\title{
IAMJ
}

INTERNATIONAL

AYURVEDIC

MEDICAL JOURNAL

\section{A PHYSIOLOGICAL STUDY OF SHUKRA DHATU W.S.R. SEXUAL HORMONES}

\author{
Prakash Choudhary $^{1}$, Rajesh Kumar Sharma ${ }^{2}$, Dinesh Chandra Sharma ${ }^{3}$, Mukesh Saini ${ }^{4}$ \\ ${ }^{1}$ P.G. Scholar, P.G. Department of KriyaSharir, DSRRAU, Jodhpur, Rajasthan, India \\ ${ }^{2}$ Professor and H.O.D., P.G. Department of KriyaSharir, DSRRAU, Jodhpur, Rajasthan, India \\ ${ }^{3}$ Associate Professor, P.G. Department of KriyaSharir, DSRRAU, Jodhpur, Rajasthan, India \\ ${ }^{4}$ P.G. Scholar, P.G. Department of KriyaSharir, DSRRAU, Jodhpur, Rajasthan, India
}

Corresponding Author:drmukeshsaini8255@gmail.com

\section{https://doi.org/10.46607/iamj3809092021}

(Published Online: September 2021)

Open Access

(C) International Ayurvedic Medical Journal, India 2021

Article Received:25/08//2021 - Peer Reviewed:04/09/2021 - Accepted for Publication:05/09/2021

\section{Check for updates}

\section{ABSTRACT}

Ayurveda has described three basic physiological constituents of the human body, viz., Dosha, Dhatu and Mala. In Ayurvedic Science, the one who has balanced Doshas, balanced Agni, properly formed Dhatus, proper elimination of Malas, well-functioning of bodily processes and whose mind, soul, senses are full of bliss is called a healthy person ${ }^{1}$. So, the formation of Dhatu is also a good indicator of good health there are seven Dhatus explained in Samhitas, those are Rasa, Rakta, Mamsa, Meda, Ashti, Majja and Shukra among all Dhatus, Shukra is considered as the sara of all other Dhatus ${ }^{2}$. Shukra Dhatu is one of the seven Dhatus in the body and Shukra is white, pure, excellent Dhatu, which is considered as best among all seven Dhatus. According to many Acharyas of Ayurveda, Garbhotpadana (reproduction) is the chief function of Shukra Dhatu, and the important fact is Shukra Dhatu also shows its effect all over the body in the form of Shukradhatusarata because Shukradhatuis located in the entire body. Sperm along with spermatic fluid and male sex hormones are also one part of Shukra Dhatu. Anu Shukra Dhatu (primordial germ cell) is essential for the Shukra Dhatu (Testosterone, Estrogen). Vitiation of Shukra dhatu shows Shukra dhatudusti (pathology) in the form of Vriddhi (hyper state) or Kshaya (waning). This vitiation may lead to main infertility and many other physical as well as psychological disorders. All Dhatus have their definite locations in the body; they are present in every cell in subtle form. Every cell possesses 
the capacity to divide or reproduce itself. Thus, one has to interpret the Garbhotpadana (reproduction) function of Shukra Dhatu. In future, it may be achievable that with the development of the facts; we will discover any content in the cell whichpossesses a definite role in cell division.Sperms along with spermatic fluid and male sex hormones are also one Partofshukra, parallel to which females possess Artava. Stri-Shukra excreted during coitus is nothing but the secretions of bartholins, cervical and endometrial glands emergence at theendoforgasm.

Keywords:Ayurveda, Stree-Shukra, Shukra Dhatu, Artava, hormones.

\section{INTRODUCTION}

According to Ayurveda, Shukra is the terminal tissue element of the body. It is considered as the Sara of all other Dhatus. As every Dhatu is located in the entire part of the body, Shukra Dhatu also occupies the whole body. A fragrance is not manifested in a flower bud, but the same is found after it blossoms, similarly to the Shukra. This means, in childhood, Shukra is present in the body in Avyakta Roopa, out as young stage is achieved, functions of Shukra appears in the body $^{3}$. According to Charak acharya Shukra is pervaded all over the sentient body such as juice in sugarcane, ghee in curd and oil in sesame seed ${ }^{4}$. Ayurve$d a$ has described three basic physiological constituents of the human body, viz., dosha, dhatu and mala. They are compared with roots of trees, as tree roots are important for its health; same as that these three constituents are necessary for human's health ${ }^{5}$. The human body is composed of Dhatus i.e. basic forms of body tissues. Dhatus are seven in number, hence called 'Saptadhatu'. They are Rasa (plasma), Rakta (formed blood cells), Mamsa (muscle tissues), Meda (fatty tissues), Asthi (bone tissue), Majja (bone marrow and nervous tissues) and Shukra (reproductive tissues). Shukra Dhatu (reproductive tissues) is present in the whole body, but its location is described around the bladder opening according to Sushruta ${ }^{6}$.Shukra is the substance that is responsible for all systemic body activities including metabolic functions and part of which comes out of the body at the time of the sexual act and performs specific functions of reproduction. It is the product of four proto elements, Vayu, Agni, Aapaa and Prithvi with all six Rasa. Shuddha-Shukra Lakshanas resembles the physical properties of the seminal fluid. Garbhottpadana i.e., fertilization is a prime function of Shukra. Garbha is formed by the fusion of Shukra and Artava $^{8}$.

This main function of Shukra is attributed to spermatozoa. While enumerating Shukra-Pradoshajavikara, it has been stated that the vitiation of Shukra hampers one's fertilizing capacity. Sushrut Acharya also has some kind of opinion he said that the seventh one Kala is Shukra Dhara Kala, which pervades the whole body of all persons, as ghee in milk and juice in sugarcane are invisibly pervasive, Shukra should also be known, means Shukra is present in the entire body of persons ${ }^{7}$. These all references as cited above, reveal that Shukra Dhatu is present in every cell of the body. Every cell can divide itself, thus we can interpret the Garbhotpadana function of Shukra Dhatu. So, it is necessary to study the basic principles and physiological concepts of Shukra Dhatu. Various scholars have quoted Vrishana or Mushka (testis), Shepha (penis), Stana (breast) and Majja (bone marrow) as Moola-Sthana (origin) of ShukravahaSrotasa (system related to reproductive tissue). These all references as cited above reveal that Shukra Dhatu is present in every cell of the body, but it is present predominantly in reproductive organs.

Shukra is Saumya which is derived from Jala Mahabhuta but Charak Acharya consider that Shukra contains all the Bhutas except Akash. All the four Bhutas (Vayu, Agni, Prithvi and Ambu) individually share one-fourth of the attributes of each of the Mahabhutas. Shukra is Pittrija Bhava Shukra Dhatu is counted as a Kapha Vargiya Dravya according to Harivansha Purana ${ }^{4}$ and also Acharya Vagbhata stated Shukra as Ashraya Sthana of Kapha Dosha. Shukra Dhatu possesses Shadrasa and one of Pranayatanas of Sharira. Shukra is one and ultimate Dhatu of the body. 
Shukra is produced as a result of successive evaluative metamorphosis of Ahara Rasa. The quantity of the Shukra Dhatu is Ardha (1/2) Anjali in the human body as per Acharya Charaka ${ }^{8}$ but Acharya Bhela stated that the quantity of Shukra is Eka (1) Anjali.

\section{MATERIAL AND METHODS \\ ETYMOLOGICAL DERIVATION}

From the Dhatu "Shuch" the word "Shukra" is derived which means cleanliness or Kledana. Then it is joining with "ran" Pratyaya with the use of Sutra "Rijendragravcceti" and makes the word "Shukra". "Shukramkli (Shuchklete + Rijendragravcceti Una Iti Ran Pratyyen Sadhu.)". .9

The derived word Shukra is having multiple meanings. They include Bright, White, and Resplendent.

\section{SYNONYMS}

Pumsatvam (Manliness), Paurusam (Vitality) Beejam (Sperm), Retas (Semen), Veeryam (Potency), Tejah (Resplendid), Anand Samudhbhav (Born out of pleasure), Majjasamudbhava (Derived from the marrow), Kittavarjitam (contains no waste materials), Majjarasa (Essence of Marrow), Balam (Strength) Dhaturasa, Roopadravya.

\section{DEFINITION}

One of the seven fundamental Tissues (Saptadhatu) - Sucre is the last Dhatu and is considered to be the quintessential sap of all the preceding Dhatus. It is strongly promoting and the most powerful among all Dhatus. Its main function is to help in Procreation, Patience, courage, fearlessness, attraction towards the opposite sex, enthusiasm, excitement, sturdiness, sexual impulse, easy secretion and ejaculation of seminal fluid during intercourse are governed by Sukra-Dhatu.

Various definitions of word "Shukra" according to different contexts,

1. A name of fire.

2. The planet Venus (Shukragraha).

3. Preceptor of Daityas.

4. A disease of the eye.

5. Silvery white substance that is ejaculated

6. The substance is white and potent.

7. A very pure and taintless substance.

8. Seventh Dhatu of the body.
9. Gold.

10. Tree of Ricinus communis.

Among all of these, "seventh Dhatu of the body", "ejaculatory silvery-white substance" and "disease of the eye" are related to Ayurveda. But in the present context, the "Seventh Dhatu of the body" and "ejaculatory silvery-white substance" appears to be most relevant and acceptable. It is clarified from the following reference: 1)"Aharasya Param Dhamamshukramtadrakshya Atmanam."10

\section{LOCATION OF SHUKRA}

Shukra is present in the whole body in the form o Shukradhara Kala. ${ }^{15}$ Its specific location is Majja Dhatu (bone marrow) and Vrishana (scrotum). ${ }^{16}$ Various scholars have mentioned roots of Shukravaha-Srotasa, they are testes, penis, breasts and bone marrow. ${ }^{17-19}$ shukra Dhara Kala is spread in the whole body, it is mainly located at the lateral side of the urinary bladder and urethra. ${ }^{20}$ In the process of coitus, Shukra which is excreted by man, enters within the female reproductive system and fertilization takes place. ${ }^{21}$ By reviewing these quotations it clarifies that Shukra maybe co-related with sperms including spermatic fluid andeven testosterone etc. sex hormones in males. Gananatha Sen has explained similarly as Antah-Shukra and Bahi-Shukra (which is absent in females). ${ }^{11}$

\section{SHUKRA ABHIVYAKTI}

The human body is made up of seven Dhatus (seven categories of tissues). Shukra is the seventh Dhatu. It is present in the whole body. It becomes active after the age of sixteen years, even though it is present since birth ${ }^{12}$.

\section{SHUKRADHATU IN CHILDREN}

Children will have Shukra in a dormant stage. This is compared to buds of flowers, which have hidden fragrances in them. The visible appears when children reach adulthood ${ }^{13}$.

\section{PANCHAMAHABHAUTIC COMPOSITION}

Acharya Charaka considers that Shukra is composed of all the Bhuta except Akasha Mahabhutai.e. Vayu, Agni, Jala and Pruthvi ${ }^{5}$. Chakrapani clarifies that Akasha Mahabhuta also dwells in Shukra due to its pervasive nature but during the ejaculation, this $M a$ - 
habhuta is absent in the Shukra and thus supports the Charaka statement. According to Acharya Sushruta, Shukra is principally Saumya (Jala Mahabhuta) as well as other Mahabhuta are also present in it, which can be proved by their function. Pruthvi, Jala, Agni, Vayu and Akasha perform the functions Dharana (to hold), Samhanana (binding), Parinama (metamorphosis), Vyuha (blow), Avakasha (spatial provision) respectively ${ }^{14}$.

\section{SHUKRADHATU IN MALE AND FEMALE}

The Shukra in women is secreted during sexual activity. However, it is not useful in Garbhotpatti. (Fertilization) Shukra (vaginal secretions) expressed during sexual activity is not capable of participating in the conjugation of sex gametes. Artava (ovum) functions for fertilization, not the secretion of female Shukra.
Charak commentator Gangadhar has explained that even females have seven Dhatus as in males. Rasa produced from Ahara serially goes through Dhatuparinaman process, producing Shukra. Sushruta commentator Dalhan Acharya has considered Artava in females as Shukra, as it is meant for conception. Therefore, he has considered Artava as Shukra in females. Vagbhata clarified that Shukra secreted by a woman is useless for fertilization. ${ }^{15}$ It is worth noting that during Shukra-Pradurbhav, some changes in mind and body also start to appear like hair growth on pubic and axillary region, shyness etc. Artava is an essential factor for conception in females, gives strength to Shukra and is responsible for strength and complexion. This means that Artava and Shukra are different.

Table 1: Shukra:- Quantity, Upadhatu, Mala, Sara:-

\begin{tabular}{|c|c|c|c|}
\hline QUANTITY OF SHUKRA & $\begin{array}{l}\text { UPADHATU OF SHUKRA } \\
\text { DHATU }\end{array}$ & $\begin{array}{l}\text { SHUKRA } \\
\text { MALA }\end{array}$ & SHUKRADHATU SARA \\
\hline $\begin{array}{l}\text { The quantity of Shukra in the } \\
\text { human body is half } \text { Anjali }^{16} \text {. }\end{array}$ & $\begin{array}{l}\text { Sharangadhara has mentioned } \\
\text { Ojas as Upadhatu of Shukra }{ }^{17} \text {. }\end{array}$ & Ojas $^{18}$ & $\begin{array}{l}\text { 1. Saumya (Gentleman) } \\
\text { 2. Saumyapreksinaha (Gentle look) } \\
\text { 3. Ksirapurnalochana (eyes appearing } \\
\text { filled with milk) } \\
\text { 4. Praharshabahula (cheerfulness) } \\
\text { 5. Snigdha-Vrittasamhata- Dasanaha } \\
\text { (teeth which are unctuous, round, } \\
\text { strong, dense, even) } \\
\text { 6. Prasanna - Snigdha-Varnasara } \\
\text { (pleasant - unctuous voice and com- } \\
\text { plexion) } \\
\text { 7. Bhrajishnuta (dazzling appearance) } \\
\text { 8. Mahaspica (large buttocks) } \\
\text { 9. Stripriya (loved by women) } \\
\text { 10. Upabhogabalavana (virile) } \\
\text { 11. Sukha (endowed with happiness) } \\
\text { 12. Aishwarya (prosperity) } \\
\text { 13. Arogya (health) } \\
\text { 14. Vitta (money) } \\
\text { 15. Sammana (honour) } \\
\text { 16. Apatyabahula (many offspring) }{ }^{19} \\
\text { 17. Dhairya and Dehabala } \\
\text { 18. Ojoposhaka }\end{array}$ \\
\hline
\end{tabular}


Table 2: Shukravaha Strotas

\begin{tabular}{|l|l|l|}
\hline Charaka & Sushruta & AstangaSamgraha \\
\hline Vrishna & Sthana & Mushka \\
\hline Shepha & Vrishna & Sthana,majja \\
\hline
\end{tabular}

\section{PROPERTIES OF SHUKRA DHATU}

The Shukra which is unctuous, dense, slimy, sweet, nonirritating \& white (transparent) like a crystal is to be known as pure or normal ${ }^{21}$.

1. The smell of pure Shukra is like honey ${ }^{22}$.
2. The Colour of Shukra is like oil or honey ${ }^{23}$.

3. It is liquid.

4. The physiological measure of Shukra Dhatu is half Anjali ${ }^{24}$.

Table 3: Characteristics Of Shukra:-

\begin{tabular}{|c|c|c|c|c|}
\hline Characteristics & Charaka & Sushruta & Astanga Sangraha & Astang Hrdaya \\
\hline A. Colour & 1. Shukla (white) & $\begin{array}{l}\text { 1. Tailanibham } \\
\text { 2.Kshaudranibham } \\
\text { (resembling oil or Hon- } \\
\text { ey) }\end{array}$ & $\begin{array}{l}\text { 1. Shuklam white) } \\
\text { 2.Ghrita Tailakshoudraan- } \\
\text { yatamavarna (resembling } \\
\text { ghee, oilor honey etc.) }\end{array}$ & $\begin{array}{l}\text { 1. Shuklam } \\
\text { (white) } \\
2 . \quad \text { Ghritamakshikataila- } \\
\text { bham (resembling ghee, } \\
\text { honey or oil) }\end{array}$ \\
\hline B. Taste & $\begin{array}{l}\text { 2. Madhuram } \\
\text { (Sweet) }\end{array}$ & 3. Madhuram & 3. Madhuram & 3. Madhuram \\
\hline C. Smell & $\begin{array}{l}\text { 3. Avisram (not } \\
\text { having a bad } \\
\text { odour) }\end{array}$ & $\begin{array}{l}\text { 4. Madhugandhi } \\
\text { (Smell of honey) }\end{array}$ & 4. Madhungadhi & ----- \\
\hline D.Consistency & $\begin{array}{l}4 . \quad \text { Bahalam- } \\
\text { (thick) } \\
5 . \\
\text { Snighdham } \\
\text { (unctuous) }\end{array}$ & $\begin{array}{l}\text { 5. Dravam (fluid) } \\
\text { 6. Snigdham } \\
\text { (unctuous) } \\
\text { 7. Sphatikabham } \\
\text { (Crystalloid in }\end{array}$ & $\begin{array}{l}5 . \quad \text { Saumyam (Jala } \\
\text { predominant) } \\
6 . \quad \text { Snigdham } \\
\text { (unctuous) }\end{array}$ & $\begin{array}{l}\text { 4. Guru (heavy) } \\
\text { 5. Snigdham(unctuous) } \\
\text { 6. Bahalam (thick) }\end{array}$ \\
\hline
\end{tabular}

\section{FUNCTIONS OF SHUKRA}

Different classics have described functions of Shukra which are as follows -

- It nourishes sub sequent Dhatu i.e. Ojas ${ }^{25}$

- It forms foetus ${ }^{10}$ anditssex ${ }^{26}$

- It can produce here dietary defects ${ }^{27}$

- It is responsible for the better men of skin texture, strength, attraction towards opposite sex and erection of penis ${ }^{28}$

- If it is vitiated by Dosha(s), it is not useful for fertilization $^{29}$

\section{STREE SHUKRA}

Seven Dhatus are present in human beings irrespective of sex. Acharya Susruta and Vagbhatta have explained the concept of Stree Shukra ${ }^{30}$. Shukra is the seventh Dhatu. It is present in the whole body. It becomes active after the age of sixteen years, even though it is present since birth in a dormant state. The concept of Stree-Shukra is discussed in classics, Susruta has mentioned that when sexual activities happen in two sexually excited women, they secrete Shukra within each other, due to which there is the formation of foetus without bones. Acharya Vagbhata has clarified that even though women secrete Shukra during coitus, it doesn't participate in fertilization $^{31}$ and embryo formation. All Dhatus have their definite locations in the body; they are present in every cell in subtle form. Stree-Shukra secreted during coitus is nothing but the secretions of Bartholines, cervical and endometrial glands emergence at 
Table 4: Ayurvedic And Modern Term Of Shukra:-

\begin{tabular}{|c|c|}
\hline Ayurvedic term & Modern term \\
\hline Shukradhatwagni & $\begin{array}{l}\text { Gonadotropic releasing hormone }(\mathrm{GnRH}) \text {, Follicular stimulation hormone } \\
\text { (FSH) and Luteinizing hormone ( } \mathrm{LH})\end{array}$ \\
\hline Shukra Dhatu in men & $\begin{array}{l}\text { In Men: - Sperm, Testosterone, Phenylethylamine Dihydrotestosterone, } \\
\text { and Androstenedione, adrenaline, dopamine, serotonin etc. }\end{array}$ \\
\hline Streeshukra in Women & Secretions of Bartholin"es, Cervical and Endometrial glands. \\
\hline Artava & Menstrual blood. \\
\hline $\begin{array}{l}\text { After fertilization portion of Artava moving in } \\
\text { the upward direction. }\end{array}$ & $\begin{array}{l}\text { Estrogen, Progesterone, Oxytocin and human chorionic gonadotropic } \\
\text { hormone. }\end{array}$ \\
\hline Streeshonita & Ovum \\
\hline
\end{tabular}

\section{CORRELATION BETWEEN SHUKRA AND HORMONES}

As we know Shukra Dhatu is produced from Majjadhatu as well as according to Ashtanga Sangraha, Moola Stana of Shukravaha-Strotas is Majja. But Dalhan-Acharya used the Majja word also for (Mastishka) Brain. By this statement, Majja means Brain and according to modern science Hapothalamus is situated in the Brain which is the controller of the Pituitary Gland. According to this information, we can relate Shukra Dhatu with Hormones, detail is as follows-Hypothalamus secrete GnRH and Hypthalamo- hypophyseal portal. The system carries this to the Anterior Pituitary. Anterior Pituitary, in response to GnRH secretes FSH and LH into the bloodstream. These hormones then circulate all over the body and stimulate ovaries and testicles to secrete their Hormones. Oozing out of Shukra may just indicate the entry of Hormones from the general circulation ${ }^{33}$. By considering all these things, it helps to know that there is relation between Hormones and ShukraDhatu, especially sex Hormones or we can say that both are the same, because the feature of Sarvadehika Shukra which are described by Ayurvedic Garantha and features of male and female sex Hormones which are described in Modern science, these two are almost same.

Tridosha and Hormones- As per the above information, Shukra Dhatu can be Compared to Hormones and from the point of view of Ayurveda, Hormones is Tridosha, this will be clear from the way they work.
The way Tridosha works is by spreading throughout the body, in the same way, Hormones works by spreading throughout the body. To confirm this, we have some proof from Ayurvedic text-

1. Ashraya Sthana of Shukra is Kapha Dosha ${ }^{34}$

2. The Shukra Dhatu quality is Soma ${ }^{35}$.

3. In the Shukra Dhatu- all Mahabhuta are present except the Akasha Mahabhuta ${ }^{36}$.

From all this information, Shukra Dhatu is Kaphapradhana and Jala Mahabhuta Pradhana. Thus, the following comparison is clear.

1. Shukra Dhatu and Hormones

2. Tridosha and Hormones

3. Shukra Dhatu and Tridosha.

\section{HORMONAL FACTORS THAT STIMULATE SPERMATOGENESIS}

Several hormones play essential roles in spermatogenesis. Some of these are as follows:

1. Testosterone, secreted by the Leydig cells located in the interstitium of the testis, is indispensable for the growth and division of the testicular germinal cells, which is the first stage in forming sperm.

2. Luteinizing hormone, released by the anterior pituitary gland, stimulates the Leydig cells to release testosterone. Stimulates testosterone production by the testis.

3. Follicle-stimulating hormone, too secreted by the anterior pituitary gland, stimulates the Sertoli cells; without this stimulation, the conversion of the spermatids to sperm will not occur. Stimu- 
lates development of ovarian follicles; regulates spermatogenesis in the testis.

4. Estrogens, formed from testosterone by the Sertoli cells when they are stimulated by folliclestimulating hormone, are probably also important for spermiogenesis.

5. Growth hormone is essential for controlling the background metabolic functions of the testes. Growth hormone especially promotes initial division of the spermatogonia themselves; in its nonappearance, as in pituitary dwarfs, spermatogenesis is gravely lacking or absent, thus causing infertility.

\section{DISCUSSION}

Dosha, Dhatu and mala are the roots of life. These are the biological forces that work through the medium of Dhatus and Malas. Dhatus and Malas are the structural units and the Doshas are the functional unit. Hence the Doshas are called Asrayees and Dhatus are called Asrayaas of Dosha. Anushukra Dhatu (primordial germ cell) is essential for the Shukra Dhatu (Testosterone, Estrogen and sperm) formation. Shukra is the seventh Dhatu. Shukra Dhatu is present in both males and females. Rasa Dhatu takes about one month to synthesize Shukra Dhatu in men or the ovum in women. Shukra of male and Shonita of the female is essential for conception. Thus, the Shonit and Shukra are responsible for Garbhotapatti and Prakriti determination.

Likewise, the entire sugar cane plant is full of its juice within it; ghee is present in all parts of the curd, oil in sesame seed. Similarly, Shukra Dhatu pervades in the entire body which has the sensation of touch. Shukra Dhatu is not present in Hair, Nail, Mala, $M u$ tra etc where blood supply is absent. Since Majja Dhatu is present in the large bones (Mahatasthisu). Acharya Charak has explained the Sneha (fatty) portion of Majja produces Shukra. The porosity in the Asthi is produced because of the factors such as Vata and Akasha. Shukra comes out of Asthi through these pores just as the water comes out of a new earthen vessel. Through the channels known as Shukravahasrotamsi, this channel spreads Shukra all over the body and remain present all over the body. Shukra dhatu is responsible for spermatogenesis and oogenesis and the expression of both primary and secondary sexual characteristics. Shukra becomes active after the age of sixteen years, even though it is present since birth in a dormant state. Acharya Vagbhata has clarified that even though women secrete Shukra during coitus, it doesn't participate in fertilization and embryo formation. All Dhatus have their definite locations in the body; they are present in every cell in subtle form. Stree-Shukra secreted during coitus is nothing but the secretions of Bartholines, cervical and endometrial glands emergence at the end of orgasm. Therefore, the female Shukra have a role in the sexual act rather than conception.

Artava (menstrual blood) is Upa Dhatu of rasa Dhatu, this Artava do not participate in fertilization. Shonita is responsible for fertilization and embryo formation. This Shonita is considered as ovum. Acharyas believe after fertilization Artava (menstrual cycle) becomes stopped due to obstruction in ArtavaSrotas. Because even though the Artavavaha-Srotas are present, these get obstructed by the presence of Garbha. Due to obstruction Artava goes up and form the Apara (placenta) and a residual portion of Artava going up and nourish the breast and prepare for milk production. This Artava is responsible for the maintenance of conception, organogenesis and development of the breast. The functions of estrogen, progesterone and prolactin come under the function of Artava formed after fertilization. The semen, which is thick, sweet, unctuous, without any putrid smell, heavy, viscid, white in colour, and abundant in quantity, invariably helps in procreation. The function of Shukra Dhatu mentioned by Acharya Susruta; Dhairya (courage), Chayvanam (ejaculation), Priti (affection), Dehabala (body strength), Harsh (exhilaration), Bijarth (procreation).

\section{CONCLUSION}

Shukra Dhatu is made from Majja Dhatu as its Sara Bhaga and it is in Kapha Pradhana form. It starts working from the brain and then it is spread all over the body through Vyana Vayu from the heart. After 
that its effect is seen all over the body such as Sarvadaihika Shukra Sara Lakshan and Maithungat Lakshan (Related with the sexual act), especially changes in Adolescence such as Excretions of Brtholines, Cervical gland secretions, Sperm with seminal fluid, growth of genital organs, development of breast, growth of hair in pubic region and axilla and development of other sexual characters. According to Ayurveda Bala, Varna, Upachaya in both sexes and besides this the most important work of Shukra Dhatu is Garbhotpadana and Nourishment of Oja Dhatu because according to Sharangdhar Acharya oja is the Upadhatu of Shukra Dhatu. Oja is known as pure Sara Bhaga of all seven Dhatu especially Shukra Dhatu. According to Some Acharyas, Oja is working as the Immunity power of the body. If the Shukra Dhatu becomes vitiated for some reason, then Oja production will also be hampered. Shukra Dhatu is one of the Dashapran-Ayatana. The above pieces of information show the importance of Shukra Dhatu.

\section{REFERENCES}

1. Sushruta Samhita, Dr Anant Ram Sharma, SusrutaVimarsini Hindi commentary Varanasi ChaukhambaSurbharatiPrakashana Varanasi 1st volume Sutrasthana chapte $5 r$ no 15 th sloka no 47 pages no 130 .

2. AstangaHrudayaSutrasthana, by Dr T Sreekumar English translation \& Commentary 1st volume chapter No 1st sloka no 13 page no 38 .

3. Acharya Vidyadhar Shukla and prof. Ravi Dutt Tripathi, Charaksamhita, chikitsathana Chapter 2/4 pada verse 39 page 67, Chaukhambaprakashan Varanasi edition 2011.

4. Acharya Vidyadhar Shukla and prof. Ravi Dutt Tripathi, Charaksamhita, chikitsathana, Chapter 2/4 pada verse 46 page 67, Chaukhamba prakashan Varanasi edition 2011

5. Gupta Atrideva, Upadhyaya Yamunadas - AshtangHridaya Samhita with Vidyotinivyakhya Hindi commentary, Sutra sthana, chapter no. 11, verse no. 1, 9th edition, Published by Chaukhamba Sanskrit Sansthan, Varanasi; 1984, p. 85.

6. Shastri Ambikadutta - Sushruta Samhita with Ayurveda Tantra Sandipika Hindi commentary, Sharirasthana, chapter no. 4, verse no. 20, re-print edition, Published by Chaukhamba Publications, New Delhi; 2010, p. 40-41.

7. Kaviraj Ambikadutt Shastri, Sushrut Samhita, sharirsthana 4/20-21 page 40-41, chaukhambapra- kashan Varanasi, edition 2016

8. 'Sushruta Samhita' Ayurveda tatvasandipika Hindi vyakhya by Ambikadatta Shashtri Published by Chaukhambha Orientalia, Varanasi, (2010) Sushruta Shareera Sthana 3/3.

9. Shabdhakalpadruma 5th part

10. Charakasamhita of Agnivesha, By Vaidya H.C.Kushwaha Edited with

11. Ayurveda Deepika ${ }^{\text {ee }}$ Hindi Commentary, 1st volume, Chaukhamba Orientalia, Varanasi.2016 Nidanasthana 6th chapter, shloka no.9, page no-565.

12. Premvati, Ayurveda prasuti-tantra evamstri-roga, part ii, chapter 9, 2nd ed., Varanasi, Chaukhamba orientalia; 1996. p. 46.

13. Shastri Ambikadutta - Sushruta Samhita with Ayurveda Tantra Sandipika Hindi commentary, Sutra sthana, chapter no. 14, verse no. 15, re-print edition, Published by Chaukhamba Publications, New Delhi; 2010. p. 66-67.

14. Bramhanand Tripathi- Agnivesha - Charaka Samhita with Ayurveda Dipika commentary of Chakrapani, Chikitsasthana, chapter no. 2/4, verse no. 39, 40. Reprint edition, Published by ChaukhambaSurbharatiPrakashan, Varanasi; 2005 p. 106.

15. Sushruta Samhita, Dr Anant Ram Sharma, Susruta Vimarsini Hindi commentary Varanasi Chaukhamba Surbharati Prakashana Varanasi 2nd volume Shareerasthana chapter no 3rd sloka no 3 pages no 29.

16. Gupta Atrideva - Ashtang Sangraha Samhita with Hindi commentary, Sharirasthana, chapter no. 1, verse no. 72, Re-print edition, Published by Krishnadas Academy, Varanasi; 1993. p. 271.

17. Charaka Samhita of Agnivesha, By Vaidya H.C.Kushwaha, Edited with

18. Ayurveda Deepika ${ }^{\text {ee }}$ Hindi Commentary, 1st volume, Chaukhamba Orientalia, Varanasi.2016 Shareersthana 7th chapter, shloka no.15, page no-849.

19. Sarngadhara Samhita of Sarngadharacarya, English Translation by Dr G.Prabhakar Rao, Chaukhambha Publication New Delhi,purvakanda 5th chapter 16th sloka page no 23 .

20. Astanga Hrudaya, Vidyotini Hindi Commentary by Kaviraja Atrideva Gupta, ChaukhambhaPrakashana2016edition, Shareerasthana 3rd chapter sloka no 63 , page no 258.

21. Acharya Vidyadhar Shukla and prof. Ravi Dutt Tripathi, Charaksamhita, vimanasathana, Chapter 8 verse 109 page 647, Chaukhamba prakashan Varanasi edition 2011

22. Dr Vinish Kumar Gupta- Akarakarabhadi yoga, in KshipraMunchan of ShukragataVata- Premature Ejaculation, Akandananda Ayurveda college, Ahmedabad, GAU, Jamnagar, Gujarat, 2009.

23. Bramhanand Tripathi- Agnivesha - Charaka Samhita with Ayurveda Dipika commentary of Chakrapani, Chikitsasthana, chapter no. 30, verse no. 145. Reprint 
edition, Published by Chaukhamba Surbharati Prakashan, Varanasi; 2005 p. 1036. 13.

24. Shastri Ambikadutta - Sushruta Samhita with Ayurveda TatvaSandipika Hindi commentary, Sharirsthana, chapter no. 2, verse no.13, Re-print edition, Published by Chaukhamba Sanskrit Sansthan Varanasi; 2005. p. 11.

25. Shastri Ambikadutta - Sushruta Samhita with Ayurveda TatvaSandipika Hindi commentary, Sharirsthana, chapter no. 2, verse no.13, Re-print edition, Published by Chaukhamba Sanskrit Sansthan Varanasi;2005. p. 11.

26. Bramhanand Tripathi- Agnivesha - Charaka Samhita with Ayurveda Dipika commentary of Chakrapani, Sharirasthana, chapter no. 7, verse no. 15. Reprint edition, Published by Chaukhamba Surbharati Prakashan, Varanasi; 2005 p. 927.

27. Agnivesha - Charaka Samhita with Ayurveda Dipika commentary of Chakrapani, Chikitsasthana, chapter no. 15 , verse no. 16, re-print edition, Published by Chaukhamba Surbharati Prakashan, Varanasi; 2008. p. 514.

28. Tripathi Bramhanand - Charaka Samhita with Charaka Chandrika Hindi commentary, Sharirasthana, chapter no. 2, verse no. 12, re-print edition, Published by Chaukhamba Surbharati Prakashan, Varanasi; 2009. p. 843.

29. Tripathi Bramhanand - Charaka Samhita with Charaka Chandrika Hindi commentary, Sutra sthana, chapter no. 28, verse no. 18, re-print edition, Published by Chaukhamba Surbharati Prakashan, Varanasi; 2009. p. 549.

30. Shastri Ambikadutta - Sushruta Samhita with Ayurveda Tantra Sandipika Hindi commentary, Sutra sthana, chapter no. 15, verse no. 7, re-print edition, Published by Chaukhamba Publications, New Delhi; 2010. p. 75.

31. Shastri Ambikadutta - Sushruta Samhita with Ayurveda Tantra Sandipika Hindi commentary, Sharirasthana, chapter no. 2, verse no. 3, re-print edition, Published by Chaukhamba Publications, New Delhi; 2010. p. 11.

32. Dalhan. Sonitavarnaniyaadhyaya. In: Trikam Y, editors. NibandhaSangraha on Sushrut Samhita. Revised edition. Varanasi (India): Chaukhamba Sanskrit Sansthan; 2009. p. 59-67.

33. Vaghbhatta. Putrakamiya Adhyaya. In: Gupta AD, editors. Astanga Sangraha. Revised edition. Varanasi (India): Chaukambha Krishnadas Academy; 2016. p. 261-271.

34. Hall JE, Guyton AC. Reproductive Physiology. In: Vaz M, editors. Textbook of medical physiology. 2nd ed. New Delhi (India): Elsevier; 2018. p. 651-696.

35. Dr Kishor Patvardhana ed, Human Physiology in Ayurveda, Pg 5865 PP74, 1st edition 2005, Chaukhambha Orientalia Varanasi.
36. VriddhaVagbhata, Ashtanga Samgraha, Sutrasthana $19 / 13$

37. KavirajAmbikadutt Shastri, Sushrut Samhita, sharirsthana $3 / 2$ page 25 , chaukhambaprakashan Varanasi, edition 2016

38. Acharya Vidyadhar Shukla and prof. Ravi Dutt Tripathi, Charaksamhita, sharirasathana, Chapter 2 verse 4 page 703, Chaukhamba prakashan Varanasi edition 2011

\section{Source of Support: Nil \\ Conflict of Interest: None Declared}

How to cite this URL: Prakash Choudhary et al: A Physiological Study Of Shukra Dhatu W.S.R. Sexual Hormones. International Ayurvedic Medical Journal \{online\} 2021 \{cited September 2021\} Available from: http://www.iamj.in/posts/images/upload/2165 2173.pdf 